\title{
Summer Research Programs for High School Students, Supporting Compo- nents
}

\section{Mrs. Claire Duggan, Northeastern University}

Claire Duggan has a B.S. in political science from the University of Massachusetts and a M.P.A. in public administration from Northeastern University. She was appointed 2003-present Director for Programs and Operations, the Center for STEM Northeastern University; 1989-2003 Associate Director, CESAME/The Center for the Enhancement of Science and Mathematics Education, Northeastern University, and K-12 Outreach Coordinator, CenSSIS/ALERT, Northeastern University; and 1981-1989 Associate Director for Finance and Administration, Center for Electromagnetics Research (CER), Northeastern University. Publications/Papers: Reenergizing and Reengaging Students Interest through CAPSULE; A Novel and Evolutionary Method on Educating Teachers to Promote STEM Careers Jessica Chin, Abe Zeid, Claire Duggan, Sagar Kamarthi (IEEE ISEC 2011); and "Implementing the Capstone Experience Concept for Teacher Professional Development" Jessica Chin, Abe Zeid, Claire Duggan, Sagar Kamarthi (ASEE 2011). Relevant Presentations: "K-12 Partnerships" (Department of Homeland Security/Centers of Excellence Annual Meeting 2009); "Building and Sustaining K-12 Educational Partnerships" (NSF ERC 2007 - 2010 National Meetings); "Research Experience for Teachers: Integrating Research Skills into the classroom" (UNH 2nd Annual Nanotechnology Conference for Teachers April 2006); and "Educational Outreach Programs" (2005 MA STEM Summit). She was Co-principal Investigator/Program Director, Research Experience for Teachers (RET), development and implementation of the Research Experience for Teachers site at Northeastern University; Executive Director/Founder, Young Scholars Program, development and implementation of the Young Scholars Program, a summer research program for high school students; Co-executive Director, Exxon Mobil Bernard Harris Summer Science Camp, development and implementation of a residential camp for middle school students; Liaison, StepUP Imitative, coordinate Northeastern University's involvement with the StepUP initiative, a partnership effort between five universities and eleven Boston Public Schools; Project Director, IMPACT New England: A Regional Curriculum Implementation Effort, coordinated program development and implementation; Seminar Leader, Northeastern University School of Education, facilitated a group of students participating in the Introduction to Education course; Project Support Liaison, Teacher Innovation program, provided support to teachers/schools in the development and implementation of Teacher Innovation Programs (TIP), provided technical assistance to teachers through the proposal process, conducted proposal-writing workshops; Co-facilitator (2004), Boston East Pipeline Network; and Alumni, Lead Boston 2004 (The National Conference for Community and Justice). She won the 2006 Northeastern University Aspiration Award, and was recognized at the 2003 Northeastern University Reception honoring Principal Investigators that obtained funding in excess of $\$ 1$ million over a five-year period.

Miss Maureen D. Cabrera, Center for STEM Education Madeline Jean Leger 


\section{Summer Research Programs for high school students, supporting components}

\section{Abstract}

The Young Scholars Program at Northeastern University provides a diverse group of high school students who have demonstrated proficiency and interest in science, technology, engineering, and math (STEM) with the opportunity to partake in a paid college laboratory research experience. The requirements of acceptance to the program are strong academic credentials and a well-rounded balance of extra-curricular activities. The program seeks to ensure that students with a demonstrated interest and ability in STEM are provided an opportunity to participate in a comprehensive research experience before completing high school. Offering this program free of charge, with a small stipend to offset transportation costs, enables all invited students to take advantage of this opportunity. Supporting program components and the execution of these elements distinguishes it from many similar summer research programs offered at universities around the country. The framework of the supporting features of Northeastern University's program is what enables participants to succeed in the labs, build self-efficacy in STEM and prepare them for their academic journey into college. The weekly schedule is supported through morning homerooms during which a variety of topics and activities are introduced, in addition to lunchtime technical seminars, and field trips to local companies and research facilities. Utilizing formative evaluations, such as weekly reflections to inform program design and implementation, allows staff to make adjustments that might be necessary to ensure a high level of participant and faculty satisfaction with the program. In addition, surveys are administered at the close of the summer program and annually to program alumni to ensure all program goals continue to be met. In their laboratory assignments, participants are guided and supported by a collaborative team of faculty, graduate and undergraduate student mentors. Mentors are provided a variety of resources to support their mentoring role prior to and throughout the summer experience. Participating faculty are also encouraged to share best practices across laboratories. This vertical mentoring approach ensures adequate guidance and support is provided to all participants both during and after completion of the summer program, ensuring participants develop confidence in STEM in addition to reinforcing their technical and scientific knowledge. Specific attention to these complementary and supporting aspects of the research program is what assures that all members succeed within an advanced laboratory environment and are provided with the additional tools and information necessary for college and career success.

Keywords: STEM, Informal Science, High School Research, Self-Efficacy

Introduction

Student persistence in college, especially in STEM fields is attributed to a number of factors including but not limited to academic readiness, their level of engagement in the institutional culture, self-efficacy, financial preparedness in addition to other supporting factors. (1) Many universities have moved to integrate a number of initiatives to support the retention of first year students including but not limited to earlier access to a research experience. In addition, informed by the success of many of these efforts, these same institutions have expanded 
early access to a research experience for secondary school students, providing direct engagement in STEM enrichment experiences prior to entering college.

The YSP program seeks to introduce high school students to an authentic research experience while also equipping them with the resources and skills that will further support their STEM persistence in higher education. Concurrently, the program seeks to engage faculty, students and staff in this experience to foster collaboration in addition to strengthening institutional support for Broader Impact efforts. The program is application-based and available to students within a commuting distance to the campus. It seeks to engage a diverse group of students with at least $50 \%$ of participants meeting one or more of the following criteria; (1) first generation college students; (2) moderate to lower income, and/or (3) from an underrepresented population in STEM (women and minority students).

Program goals and objectives are aligned with recommendations made to increase the engagement of underrepresented students in STEM, ${ }^{(6)}$ but also seeks to engage a socially and economically diverse group of participants in the program experience to model early the environment students will need to navigate upon entering college. Our program goals and objectives are to:

a. Provide high school participants an authentic summer research experience.

b. Provide participants an opportunity to learn about cutting edge research in engineering and other STEM fields.

c. Introduce participants to a STEM support community that will transcend program participation consisting of faculty, students, program alumni and peers.

d. Provide opportunities for faculty and university students to support K12 students through mentoring and research support.

e. Provide participants essential information regarding applying to and succeeding in college.

f. Increase the participants' awareness of STEM careers, with an emphasis on Engineering and associated educational pathways.

Recruitment and selection

Program information and applications are distributed at regional STEM events, distributed directly to STEM teachers and guidance counselors in addition to being available on a program website. Program participants must live within a commuting distance to the campus and commit to full program participation. Application and selection consists of a formal application, essay, teacher recommendations, and academic transcripts. All applications are reviewed by a minimum of three reviewers. Applicants prioritize their research interests but are not guaranteed a placement in any particular laboratory.

Research assignments are solicited from interested faculty early in the spring semester for the summer program. Essential skills and competencies are outlined to facilitate final student 
selection and placement. It is essential to identify and place participants in a research assignment that clearly articulates and specifies required skills and content knowledge. This certifies that the students will reap the benefits of the mentoring and supportive culture that the participating faculty works so hard to build within their laboratories. Invited faculty and their staff have prior experience with mentoring undergraduate students during the academic year through participation in programs such as the Research Experience for Undergraduates (REUs). The roles and responsibilities of laboratory staff as mentors to YSP participants and the supporting roles of YSP program staff is clearly outlined prior to the start of the summer. Team placement is determined to be in the best interest of the laboratory and the participant alike. The personality and interests of the participant is gauged based on their application answers, which is then used to identify good team fits. The method of pairing students in labs works well because prior observation and feedback has shown that they are more willing to share their concerns and raise questions with the support of a fellow participant.

Additional/supporting program components

Driven by recommendations in reports such as "Rising Above the Gathering Storm" (2) and "Increasing Persistence of College Students in STEM" (3) there is a growing number of summer research programs designed to introduce students to STEM early in their academic journey. Programs for secondary students vary from course based experiences to independent study similar to what is available to a college student. These early college experiences provide students the opportunity to develop skills essential to future college and career success. The YSP program provides participants with a free, challenging research experience complemented and supported by additional program elements generally not introduced until the first year of college. Guided by exemplary practices ${ }^{(4)}$ to increase student retention, these complementary experiences fall into one of the following categories:

Academic preparedness

Students selected to participate in this program have demonstrated competency in STEM in one or more of the following ways; traditional coursework, extracurricular courses and/or experiences and/or self-directed study. Additional training is provided as needed for laboratory specific assignments in such areas as CAD and Matlab.

Academic engagement and/or integration

Development, selection, and placement of project teams in participating laboratories is addressed through assessment of skills required in identified assignments and review of each applicants coursework and competencies. It is essential for students to be prepared for the assignment outlined. In addition, although not (formalized) attention is made to additional extracurricular activities/interests of project teams and laboratory staff.

Laboratory assignments are proposed well in advance of applicant selection and utilized in the final decision process. Teams are introduced to faculty and supporting personal through a welcome session/orientation, and provided introductory reading and course material through a companion website in advance of the official program start date. 
Faculty and students supporting participants in the laboratory are selected based on prior research mentoring experience and or direct engagement in Broader Impact efforts. Initial participation for faculty new to working with K12 populations is often suggested to entail providing seminars and/or workshops to program participants during their first year collaborating in the program. Additionally, faculty supporting this program effort for multiple years are encouraged to share their experiences and recommendations to new program supporters. Faculty are encouraged to utilize the tools available in such sites as WEBGURU ${ }^{(5)}$ to prepare initial research assignments in addition to considering laboratory processes that might be put in place which will support both high school and undergraduate research participants in the laboratory.

Social networking sites such as Facebook are utilized formally by program staff through a closed Facebook Program page in addition to being utilized by program participants directly and support formative evaluation efforts of the program. Participants are required to maintain laboratory notebooks and complete weekly reflections on their experiences within the laboratory. Within these reflections there are questions regarding the supporting components such as additional seminars and field trips.

The program commences with an orientation at which an overview of core program requirements is provided and participants meet faculty, staff, and fellow young scholars. At this time the essential university requirements such as laboratory safety, how to utilize university resources and facilities, and public safety are addressed. Information regarding specific research assignments is shared with all participating faculty and graduate students.

Each summer research offerings vary based on faculty interest and availability. Given the duration of this program, there is a considerable amount of faculty interest and commitment that allows them to opt in and out of program participation each summer and continue to meet our program goals.

(Table 1 of most recent research assignments)

\begin{tabular}{|l|l|}
\hline Title & Abstract \\
\hline $\begin{array}{l}\text { Nanoparticle- } \\
\text { Based Gene } \\
\text { Delivery }\end{array}$ & $\begin{array}{l}\text { The purpose of this study will be modulating macrophage functional } \\
\text { polarity by nanoparticle-based gene delivery systems for anti-inflammatory } \\
\text { effect. Macrophages are phagocytic cells with important functions in } \\
\text { orchestrating an immune response to infection/inflammation. } \\
\text { Anti- }\end{array}$ \\
$\begin{array}{l}\text { Macrophages alternate between two distinct phenotypes pro- } \\
\text { Therapy }\end{array}$ & $\begin{array}{l}\text { inflammatory (M1) and anti- } \\
\text { inflammatory (M2) macrophages. Modulating their phenotypes from M1 to } \\
\text { M2state would provide a potential therapeutic mechanism against chronic in } \\
\text { flammatory diseases. The YSP students will try to prepare and characterize } \\
\text { nanoparticle-based gene delivery systems, and perform in vitro macrophage } \\
\text { polarization study. }\end{array}$ \\
& $\begin{array}{l}\text { Atherosclerosis, a blood vessel disease defined by arterial hardening due to } \\
\text { tissue remodeling and plaque buildup, occurs at artery branches where }\end{array}$ \\
\hline
\end{tabular}




\begin{tabular}{|c|c|}
\hline $\begin{array}{l}\text { Communication } \\
\text { and "Sugar } \\
\text { Coating" }\end{array}$ & $\begin{array}{l}\text { blood flow is unstable. The research group is conducting basic research to } \\
\text { study the impact of blood flow-derived forces on the integrity of blood } \\
\text { vessel endothelial cells, which make up the protective skin of the inner } \\
\text { blood vessel wall and are the first line of defense against atherosclerosis. } \\
\text { Since atherosclerosis is a precursor to heart attack, stroke, aneurysm, } \\
\text { peripheral vascular disease, and retinal vascular disease, this research is } \\
\text { critical for solving serious and costly societal health problems. }\end{array}$ \\
\hline $\begin{array}{l}\text { Experimental } \\
\text { Comparison of } \\
\text { Two Brain } \\
\text { Interfaced } \\
\text { Typing } \\
\text { Paradigms }\end{array}$ & $\begin{array}{l}\text { CSL developed a unified software framework in Matlab, which allows for } \\
\text { individuals with locked-in syndrome and other severe speech and motor } \\
\text { disabilities to use their brain signals to type. This framework currently has } \\
\text { RSVP Keyboard and Matrix Speller paradigms for alphabet presentation } \\
\text { and brain stimulation. The summer interns will learn how to use the existing } \\
\text { software and EEG hardware to run experiments, collect data from healthy } \\
\text { participants, and perform statistical tests on acquired data to evaluate three } \\
\text { forms of visual stimulus presentation in this brain interfaced typing } \\
\text { framework. The work includes experiment design, experimental data } \\
\text { collection, and statistical data analysis. An understanding of brain computer } \\
\text { interface systems will be developed through active engagement in the BCI } \\
\text { team at CSL. }\end{array}$ \\
\hline $\begin{array}{l}\text { Social Media } \\
\text { Analytics }\end{array}$ & $\begin{array}{l}\text { SMILE lab focuses on the frontier research of applied machine learning, } \\
\text { social media analytics, human-computer interaction, and high-level image } \\
\text { and video understanding. Our research is driven by the explosion of diverse } \\
\text { multimedia from the Internet, personal or publicly available photos and } \\
\text { videos. We start by treating fundamental theory from learning algorithm as } \\
\text { the soul of machine intelligence and arm it with visual perception. What } \\
\text { follows is a synergetic media learning system that not only actively collects } \\
\text { massive visual information from the environment, but also processes and } \\
\text { responds human interactively with precise analysis and possible } \\
\text { suggestions. Depending on the level of math and software knowledge, } \\
\text { participants can engage in our projects with an appropriate contribution, or } \\
\text { they can choose to develop their own project if they want. We will } \\
\text { provide sufficient resources to facilitate such explorations. }\end{array}$ \\
\hline $\begin{array}{l}\text { Building } \\
\text { Nanotube Fiber } \\
\text { Electrical } \\
\text { Fusion System }\end{array}$ & $\begin{array}{l}\text { This research focuses on a novel carbon nanostructure engineering process } \\
\text { called nanotube fusion. This highly controllable method controls input } \\
\text { voltages across the network to create covalently bonded molecular junctions } \\
\text { (cross-links) between CNTs, transforming them into larger diameter single- } \\
\text { walled CNTs, multi-walled CNTs, or multi-layered graphene nanoribbons } \\
\text { with tremendous property improvement. The overall research objective of } \\
\text { this project is to create high-performing fibers for applications in aerospace, } \\
\text { high power density energy storage, lightweight cabling/wiring, structural } \\
\text { health monitoring, and more. }\end{array}$ \\
\hline
\end{tabular}




\begin{tabular}{|c|c|}
\hline $\begin{array}{l}\text { Bio-MEMS } \\
\text { Approaches to } \\
\text { Advance Point } \\
\text { of Care } \\
\text { Diagnostics, } \\
\text { Cell Culture } \\
\text { and Drug } \\
\text { Screening, and } \\
\text { Delivery } \\
\text { Methods }\end{array}$ & $\begin{array}{l}\text { The lab is focused on developing novel Bio-MEMS approaches to advance } \\
\text { point of care diagnostics, cell culture and drug screening and delivery } \\
\text { methods. This lab has developed the Lab-on-a-Chip (LOC) devices that } \\
\text { integrate several laboratory functions such as real time monitoring of target } \\
\text { clinically relevant analyte, proteomics, genomics, cell-cell interactions as } \\
\text { well as cell secretion and surface monitoring of single cells on a micro-chip. } \\
\text { The advantages of the microfluidic based LOC developed by the lab } \\
\text { include, the pico and nano-liter volumes, elimination of cross- } \\
\text { contamination, the fast and efficient mixing of reagents and gases and the } \\
\text { ability to manipulate and analyze cells at a very high-throughput. }\end{array}$ \\
\hline $\begin{array}{l}\text { Building Next } \\
\text { Generation } \\
\text { Solar Panels }\end{array}$ & $\begin{array}{l}\text { This project will build new types of solar panels. The approach will be to } \\
\text { create small panels that have electronics integrated in them. The small } \\
\text { panels will be able to clip on to each other in a plug and play fashion to } \\
\text { build up power. The panels will communicate with each other and } \\
\text { ultimately be able to: 1) self-heal when there are faults in the system, 2) } \\
\text { optimize energy extraction by adopting their operation according to light } \\
\text { intensity, and 3) create a stable output voltage for battery chargers. The } \\
\text { YSP student will help design various aspects of the solar photovoltaic } \\
\text { system, including mechanical layout, fuses, electric circuits, simulation } \\
\text { models in CAD and/or MATLAB. Extensive experimentation in solar } \\
\text { energy will occur both outside as well in the indoor lab. }\end{array}$ \\
\hline $\begin{array}{l}\text { Creating } \\
\text { Actuated Self- } \\
\text { folding Tissue } \\
\text { Scaffold } \\
\text { Architectures } \\
\text { Based on } \\
\text { Nanoporous } \\
\text { Membranes }\end{array}$ & $\begin{array}{l}\text { Tissue engineering can save lives by supplementing the supply of organ } \\
\text { transplants and by enabling the screening of new medical therapies before } \\
\text { any human testing takes place. However, it is also incredibly } \\
\text { complex. Tissues cannot survive without an adequate supply of nutrients } \\
\text { and oxygen, or without removal of metabolic byproducts. Vascular } \\
\text { networks provide these functions in most human tissues, but it has proven } \\
\text { difficult to create effective vasculature in engineered tissues. A seemingly } \\
\text { simple solution would be to seed cells onto a scaffold and let the developing } \\
\text { tissue form its own vasculature, but research has shown that the resulting } \\
\text { vascular networks are not sufficiently well-organized to supply the tissue. } \\
\text { Despite the progress represented by this research, available techniques for } \\
\text { tissue engineering are still limited by the need for serial processing (which } \\
\text { limits throughput), an inability to produce truly 3D vascular networks, or } \\
\text { both. } \\
\text { The purpose of our research is to create tissue with excellent structural } \\
\text { control and high throughput through a scalable process. In this process, the } \\
\text { different types of cells that make up the tissue are first assembled onto a } \\
\text { two-dimensional polymer scaffold sheet using a process that precisely } \\
\text { controls the cells' positions on the sheet. The sheet is then origami folded } \\
\text { into three dimensions so that the cells align to create the proper tissue }\end{array}$ \\
\hline
\end{tabular}




\begin{tabular}{|c|c|}
\hline & $\begin{array}{l}\text { features. In this way, the ability to organize cells in two dimensions will } \\
\text { enable the creation of fully three-dimensional tissue. }\end{array}$ \\
\hline $\begin{array}{l}\text { Project \#2: } \\
\text { Processing of } \\
\text { Physiologic } \\
\text { Optical Images } \\
\text { and Signals for } \\
\text { Development of } \\
\text { an } \\
\text { Intraoperative } \\
\text { Burn Surgery } \\
\text { Diagnostic } \\
\text { Device. } \\
\\
\text { Project \#3: } \\
\text { Multimodal } \\
\text { Breast Cancer } \\
\text { Detection: X- } \\
\text { ray, NRI and } \\
\text { Thermoacoustic } \\
\text {-tomography. }\end{array}$ & $\begin{array}{l}\text { Project \#1: We are developing a new radar system concept, capable of } \\
\text { detecting explosive related threats at standoff distances. The system consists } \\
\text { of a two dimensional aperture of randomly distributed } \\
\text { transmitting/receiving antenna elements and a set of Passive Reflecting } \\
\text { Surfaces (PRS) positioned in the vicinity of the target. A 3D imaging } \\
\text { algorithm, based on novel compressive sensing techniques, is used in this } \\
\text { work. } \\
\text { Project \#2: As a part of this project, we will be using machine learning } \\
\text { techniques to differentiate the wound bed from the de-vitalized burn tissue } \\
\text { and healthy skin using multi-/hyper-spectral imaging data. Additionally, we } \\
\text { will study signal features that will help to assess the following: 1) the } \\
\text { severity of the burn; 2) oxygen and/or hemoglobin content of the patient's } \\
\text { healthy skin and wounded tissues; } 3 \text { ) fluid resuscitation status of the patient; } \\
\text { and 4) cardiovascular status of the patient. } \\
\text { Project \#3: We are developing an early breast cancer imaging system that } \\
\text { combines } 3 \mathrm{D} \text { Microwave Nearfield Radar Imaging (NRI) and Digital Breast } \\
\text { Tomosynthesis (DBT). The new fused modality system will provide an } \\
\text { important public service to our society, addressing the most common of } \\
\text { women's cancers. Preliminary results show that imaging the breast using } \\
\text { the phase of the nonuniform Green's function can produce high fidelity } \\
\text { images for breast cancer detection. Finally, we are also studying how } \\
\text { thermoacoustic tomography can complement the aforementioned } \\
\text { technology. }\end{array}$ \\
\hline $\begin{array}{l}\text { Fundamental } \\
\text { Research on } \\
\text { Combustion }\end{array}$ & $\begin{array}{l}\text { This research includes fundamental combustion studies such as flame } \\
\text { propagation speed, flame stability, auto-ignition and development of } \\
\text { chemical kinetics model to save computational time for combustion } \\
\text { modeling. Experiments are performed in cylindrical and spherical vessels. } \\
\text { Flame structure and flame stability analyses are done in the cylindrical } \\
\text { vessel using a high speed camera. Flame speeds have been measured using } \\
\text { both vessels. Different fuels such as bio-fuel and other conventional fuels }\end{array}$ \\
\hline
\end{tabular}




\begin{tabular}{|c|c|}
\hline & $\begin{array}{l}\text { are used in these studies. Burning speeds of fuel/air/diluent mixtures over a } \\
\text { wide range of pressures, temperatures and equivalence ratios are measured. }\end{array}$ \\
\hline $\begin{array}{l}\text { Graded } \\
\text { Architecture } \\
\text { Composites }\end{array}$ & $\begin{array}{l}\text { This project will make use of colloidal assembly techniques to create hybrid } \\
\text { particles with multi-scale morphology to reinforce polymer-based } \\
\text { discontinuous composites. This assembly process will enable formation of } \\
\text { materials with graded architectures. }\end{array}$ \\
\hline $\begin{array}{l}\text { Human } \\
\text { Tracking Using } \\
\text { Vision and } \\
\text { Sonar }\end{array}$ & $\begin{array}{l}\text { The goal for this project is for the student to develop a system for human } \\
\text { tracking using vision and/or sonar. Human tracking is important in a } \\
\text { robotics context because robots typically need to interact with people. In } \\
\text { this case, the robot will use vision algorithms to track the motion of the } \\
\text { person and potentially move the robot head in order to keep the person in } \\
\text { the center of view. Sonar may be used as a way of coarsely estimating the } \\
\text { human position. }\end{array}$ \\
\hline $\begin{array}{l}\text { Advanced } \\
\text { Imaging } \\
\text { Technology } \\
\text { Radar Security } \\
\text { Sensing }\end{array}$ & $\begin{array}{l}\text { The Advanced Imaging Technology project began Fall, } 2010 \text { with the goal } \\
\text { of developing an improved multi-modality portal-based passenger screening } \\
\text { system. Millimeter-wave, x-ray backscatter, infrared sensing, and Terahertz } \\
\text { sensing are being considered. Initial concentration in mm-wave imaging } \\
\text { makes use of optimal antenna placement, model-based inversion, superior } \\
\text { frequency specification, and custom designed radar hardware. A specially- } \\
\text { built hardware platform has been designed and built. Consisting of } \\
\text { mechanical and electrical subcomponents it will facilitate reconfigurable } \\
\text { sensor placement in order to develop a multi-static imaging radar system. }\end{array}$ \\
\hline $\begin{array}{l}\text { Modeling Human } \\
\text { Movement }\end{array}$ & $\begin{array}{l}\text { Human movement consists of a complex system of joints and linkages } \\
\text { working together to produce coordinated movements. Muscles create torques } \\
\text { around the joints to produce movements. In disease diagnosis and monitoring, } \\
\text { rehabilitation, and sports performance, it is helpful to know which muscles are } \\
\text { active during a particular movement. To do this, we use musculoskeletal } \\
\text { computer models of the bones, joints and muscles. Because there is more than } \\
\text { one combination of muscle activities that can create a motion, optimization } \\
\text { routines are used to determine the most likely activation patterns. In this } \\
\text { project, we will use the open source OpenSimmTK modeling software to } \\
\text { create models of walking and exercise and examine the effects of muscle } \\
\text { weakness on joint loads. Such models can be used to inform physical therapy } \\
\text { regimes, determine rehab progression, or as biometric feedback on sports } \\
\text { performance. }\end{array}$ \\
\hline
\end{tabular}

Schedules, presentations, and supporting documents are readily accessible to participants. A closed electronic platform is utilized prior to and throughout the duration of the program. This site helps them review the weekly events, access presentations and review additional resources shared over the course of the program. This information is also useful for students as they 
maintain their program journal. Journals are reviewed by program staff and responded to accordingly. Weekly reflection and feedback have proven to be essential to addressing program challenges. Challenges that have been addressed as a result of journal entries include lack of supervision in the lab, anxiety, unreasonable assignment/expectations, etc.

\section{Social engagement and or integration}

Social integration is essential to build and sustain long term relationships between students and project staff, especially for students that are often isolated within their own high school environments. Team building activities are integrated into orientation and homeroom sessions. Mentoring by university students occurs both formally by dedicated summer program and laboratory staff and informally by their peers from student organizations. Students are encouraged to maintain contact with each other, alumni from previous years, and with program and laboratory staff. Our most recent YSP alumni survey found 92\% of respondents thought that the laboratory component of the program was either "valuable" $(27.4 \%)$ to "very valuable" (64.7\%). "When asked to rate the additional program elements $83 \%$ of respondents indicated they were "valuable" (54.9\%) to "very valuable" (27.5\%). The participants' responses about how they valued the social community created within the program resulted in over $90 \%$ indicating the program to be "valuable" (33\%) to "very valuable" (59\%). This feedback reflects the fact that young scholars regarded the social environment and supporting features of the program almost as valuable as the laboratory experience itself.

The following table represents the most recent survey given to all YSP alumni. Its findings validate the claims made in this paper. The Likert scale weighted each of the possible answers from 1-5 (1 being "very little, 2 "somewhat," etc). The weighted average reflects the strength of the data.

Table 1

\begin{tabular}{|l|l|l|l|l|l|l|}
\hline Questions & $\begin{array}{l}\text { Very } \\
\text { Little }\end{array}$ & $\begin{array}{l}\text { Somewha } \\
\mathrm{t}\end{array}$ & Neutral & Valuable & $\begin{array}{l}\text { Very } \\
\text { Valuable }\end{array}$ & $\begin{array}{l}\text { Weighted } \\
\text { Average }\end{array}$ \\
\hline $\begin{array}{l}\text { To what extent did your } \\
\text { YSP participation affect } \\
\text { your choice of } \\
\text { college/major? }\end{array}$ & $0 \%$ & $12.24 \%$ & $12.24 \%$ & $42.86 \%$ & $32.65 \%$ & 3.96 \\
\hline $\begin{array}{l}\text { Reflecting back on the } \\
\text { summer experience, how } \\
\text { valuable was the } \\
\text { laboratory component of } \\
\text { the program? }\end{array}$ & $0 \%$ & $3.92 \%$ & $3.92 \%$ & $27.45 \%$ & $64.71 \%$ & 4.53 \\
\hline $\begin{array}{l}\text { Reflecting back on the } \\
\text { summer experience, how } \\
\text { valuable were the } \\
\text { additional program }\end{array}$ & $3.92 \%$ & $0 \%$ & $13.73 \%$ & $54.90 \%$ & $27.45 \%$ & 4.02 \\
\hline
\end{tabular}




\begin{tabular}{|l|l|l|l|l|l|l|}
\hline $\begin{array}{l}\text { elements? (homeroom/ } \\
\text { college application } \\
\text { process/financial aid } \\
\text { information etc.? }\end{array}$ & & & & & & \\
\hline $\begin{array}{l}\text { Reflecting back on the } \\
\text { summer experience, did } \\
\text { you find it valuable to be } \\
\text { in a social community } \\
\text { with students with similar } \\
\text { interests in math/science } \\
\text { and/or engineering? }\end{array}$ & $0 \%$ & $0 \%$ & $7.84 \%$ & $33.33 \%$ & $58.82 \%$ & 4.51 \\
\hline $\begin{array}{l}\text { How important was the } \\
\text { fact that the program was } \\
\text { offered at no cost to you, } \\
\text { and actually provided a } \\
\text { stipend, to your } \\
\text { participation? }\end{array}$ & $0 \%$ & $2.04 \%$ & $6.12 \%$ & $42.86 \%$ & $48.98 \%$ & 4.39 \\
\hline
\end{tabular}

Morning homeroom and lunchtime sessions provide an opportunity to address daily attendance in addition to providing time to discuss any challenges and/or concerns participants might have. Each summer we include the following sessions in addition to having sufficient time and flexibility to have additional program offerings.

College application process/completing your essay

Students learn the basics about the Common App and how to write an effective college essay. They are required to write two drafts that are reviewed by program staff. The staff continues to be a resource to the student after program completion.

Freshman 101

Additional information is shared regarding engaging in student organizations/clubs, alternative living arrangements such as living learning communities are discussed in these sessions.

\section{E-Portfolio's}

Sessions address traditional and non-traditional documentation of academic work and competencies acquired through participation in the summer program.

Technical seminars

Seminars vary each year depending on available faculty. Students have showed great interest in learning about their peers' labs. 


\section{STEM policy}

A session is offered on the real life implications of careers in STEM along with how policy affects those respective businesses. This topic is also integrated in many other aspects of the program.

\section{Career Opportunities}

Weekly field trips are schedule to an array of corporate and government research facilities to ensure participants are exposed to a broad range of career/employment options for STEM professionals.

Financing college

Ensuring program participants and their parents have information on financing their higher education is an essential program component. These sessions have been expanded beyond Financial Aid topics to include information on scholarship offerings, work experiences that might be accessed during their academic course of study, etc. The center commits to providing this program free of charge to ensure family's ability to set aside funding for college rather than participation in this experience. In the most recent alumni survey, one past participant said:

"I think it's fantastic that YSP can involve students from a broader socio-economic spectrum in research early. Way too often only students who can afford to volunteer their time over the summer get these opportunities."

That same survey showed that $90 \%$ of alumni found the fact that the program was offered at no cost to them, and actually provided a stipend, was "important" (40\%) to "vital" (50\%) to their participation.

Final presentations

The six week program concludes with final presentations and a poster session open to all participating faculty, family, and the broader university and school partnership community. This culminating experience completes their academic requirements and introduces skills that will be required during participant's undergraduate experience. This event also serves as a conclusion of the official mentoring role by faculty and laboratory staff.

Summary/conclusion/recommendations

The YSP program, launched in 1989 in response to national recommendations ${ }^{(8)}$ has been refined each year through the direct input of participants, university students, faculty and staff. The program timeframe, research assignments and supporting components have facilitated the expansion of a supportive STEM community for those entering the STEM Pipeline. The program has informed participants of the range of STEM pathways, information alumni have referenced as very valuable in their final college/career decisions

One alumni student affirmed our claims when they mentioned in the most recent survey that, 
"The YSP was definitely a life changing experience, providing me with the opportunity to perform university research and discover my interests. It also greatly helped me navigate through the college application process and hone my essay. I think YSP is a great program that expertly selects students. I don't know if I would necessarily consider expanding YSP (because the small atmosphere really creates a sense of community), but if more universities in the Boston-area could have YSP-like programs, that would create more opportunities for students in the Boston-area."

There have been 414 high school students through YSP since its inception.

- $85 \%$ of second-generation alumni are enrolled in or have completed a bachelor's degree program in a STEM field.

- Alumni increasingly serve as a resource for new program participants, often volunteering to give presentations for current participants of the summer program.

- Alumni have also now moved forward to share their interest in STEM with younger students through leading and/or supporting educational outreach efforts at their own institutions in addition to those offered at Northeastern University.

The program model provides high school students the opportunity to engage in an authentic research experience; build self-efficacy in STEM; provides a framework and supporting components for faculty to address Broader Impact ${ }^{(9)}$ requirements; engages undergraduates and graduate students in mentoring and direct instruction and expands a now well-established STEM community to further enhance our national STEM capacity.

Bibliography

1. (Tinto, V. (1975). Dropouts from higher education: A theoretical synthesis of recent research. Review of Educational Research, 45, 89-125.

2. Committee on Prospering in the Global Economy of the 21st Century: An Agenda for American Science and Technology, National Academy of Sciences, National Academy of Engineering \& Institute of Medicine . (2007). Rising above the gathering storm: energizing and employing America for a brighter economic future, National Academies Press.

3. Increasing Persistence of College Students in STEM SCIENCE EDUCATION Mark J. Graham, 1, 2 Jennifer Frederick, 1 Angela Byars-Winston, 3 Anne-Barrie Hunter, 4 Jo Handelsman 27 SEPTEMBER 2013 VOL 341 SCIENCE 
4. Demetriou, C. \& Schmitz-Sciborski, A. (2011). Integration, motivation, strengths and optimism: Retention theories past, present and future. In R. Hayes (Ed.), Proceedings of the 7th National Symposium on Student Retention, 2011, Charleston. (pp. 300-312). Norman, OK: The University of Oklahoma.

5. "WebGURU." WebGURU. N.p., n.d. Web. 15 Mar. 2016. <http://www.webguru.neu.edu/>.

6. National Academy of Sciences (US), National Academy of Engineering (US), and Institute of Medicine (US) Committee on Underrepresented Groups and the Expansion of the Science and Engineering Workforce Pipeline. Washington (DC): National Academies Press (US); 2011.

7. National Science Board (2010). Preparing the next generation of STEM innovators: Identifying and developing our nation's human capital. Retrieved from http://www.nsf.gov/nsb/publications/2010/nsb1033.pdf

8. United States. National Commission on Excellence in Education. (1983). A nation at risk: The imperative for educational reform: a report to the Nation and the Secretary of Education, United States Department of Education. Washington, D.C.: The Commission.

9. National Science Foundation Grant Proposal Guide (2013). NSF 13-1 Chapter III - NSF Proposal Processing and Review: A. Merit Review Principles and Criteria 